\title{
Benign Lesions of Larynx - A Clinicopathological Study
}

\author{
Aniket R. Buche ${ }^{1}$, Sachin H. Garud ${ }^{2}$, Subhalakshmi A. Jaiswal ${ }^{3}$, Gaurav A. \\ Chamania $^{4}$ \\ ${ }^{1}$ Assistant Professor, Dept. of ENT \& Head-Neck Surgery, SVNGMC, Yavatmal, Maharashtra, India \\ ${ }^{2}$ Assistant Professor, Dept. of ENT \& Head-Neck Surgery, SVNGMC, Yavatmal, Maharashtra, India \\ ${ }^{3}$ Professor \& HOD, Dept. of ENT \& Head-Neck Surgery, VMGMC, Solapur, Maharashtra, India \\ ${ }^{4}$ Junior Resident, Dept. of ENT \& Head-Neck Surgery, SVNGMC, Yavatmal, Maharashtra, India
}

\begin{abstract}
:
Objective: Study was embarked upon to study the incidence of various types of benign lesions of larynx and their modes of clinical presentation, etiological factors and correlate the clinical and histopathological diagnosis.

Patients: A total of 40 patients with benign laryngeal lesions were involved in the study with Hoarseness/change in voice; difficulty in breathing; foreign body sensation in the throat; pain on speaking and fatigue of voice and common cold; the findings were correlated with indirect laryngoscopy;. The patients were in the age group of 962 years. Patients with clinical diagnosis of malignancy of larynx; all cases with inflammatory lesions; patients with speech defect due to central nervous system (CNS) lesions; patients with oral and pharyngeal pathology; and cases with nasal and nasopharyngeal pathology, were excluded from the study.

Results: Male preponderance was seen i.e. 25 cases (62.5\%) with male to female ratio 1.67:1. Most patients constituted the age group 21-30 years. Vocal Cord nodules werefound to be the most common type of lesion with 18 cases (45\%). Housewives were found to be the most afflicted group 10 cases (25\%). Vocal Abuse was found to be most common predisposing factor 25 cases $(62.5 \%)$ and most common presenting symptom was Hoarseness of Voice (100\%).

Keywords:benign lesions larynx, clinicopathological, histopathological, hoarsness of voice, microlaryngoscopic examination, , vocal cord nodule, vocal cord polyp
\end{abstract}

\section{Introduction}

Voice is the natural medium well adapted to communicate emotional content, whereas speech is a cultural medium that is suitable to convey intellectual content. Speech may be used to express feelings but also to hide, disguise or deny them. ${ }^{1}$

Only vertebrates with their thoracoabdominal diaphragms are able to use their larynges as flutter valves; altering air flow from their respiratory bellows to produce sound. The production of sound for communication of complex information is limited highest orders. ${ }^{2}$

Although rarely life threatening, voice problems can cause tremendous alteration in daily living and should not be underestimated as a medical disorder. ${ }^{3}$

Voice disorder can have a significant influence on vocational, social and the emotional adjustment of patients. Physicians particularly otolaryngologists, usually are first person approached when voice sounds abnormal.Benign neoplasms of the larynx constitute an interesting array of lesions and have been defined as "An abnormal mass of tissue in the larynx, the growth of which exceeds and is uncoordinated with that of normal tissue and persists in the same excessive manner after cessation of stimuli which evoked the change". 4

Recently benign lesions of larynx are becoming quite common because of increased environmental pollution due to rapid industrialization and development. The incidence has increase also because of talking loudly in noisy area in routine. Benign lesions of larynx are fairly common problem in ENT. The vocal cord have got a vital function of voice production and facilitate communication. Any lesion of it causes disturbance in routine life of person not only because of early prejudice of the airway but also because of the interference with the function in some cases. Some cases of benign lesions also present with anomalous features like that of malignant lesion. So it is very essential to diagnose and treat such problem effectively in time by knowing all details about it. ${ }^{5}$

\section{Aims And Objectives}

The aims and objectives of this study were to study the incidence of various types of benign lesions of larynx and the various modes of clinical presentation, to evaluate the etiological factors of benign lesion of larynx. And correlate the clinical and histopathological diagnosis. 


\section{Material \& Methods}

Patients having signs and symptoms related to laryngeal disorders were selected after provisional diagnosis of benign lesion of larynx in E.N.T. OPD for direct laryngoscopy and microlaryngoscopic examination.

The patients were selected on the basis of the following inclusion and exclusion criteria.Inclusion criteria: Hoarseness/change in voice; difficulty in breathing; foreign body sensation in the throat; pain on speaking and fatigue of voice; common cold and the findings were correlated with indirect laryngoscopy;Exclusion criteria: Patients with clinical diagnosis of malignancy of larynx; all cases with inflammatory lesions; patients with speech defect due to central nervous system (CNS) lesions; patients with oral and pharyngeal pathology; and cases with nasal and nasopharyngeal pathology.

The record of details of symptomatology, investigation and management of the cases was kept with a particular consideration of the following points. Age, sex, occupation and address. Symptoms of the patients; Change in voice / hoarseness of voice Inability to raise the voice, Foreign body sensation in the throat, Easy fatigability of the voice, Discomfort in throat, Breathlessness / stridor, Persistent or irritant cough with or without expectoration. Personal history of the patient; Vocal abuse / misuse of voice, Exposure to irritant atmosphere (industrial exposure), Smoking and tobacco chewing, betel nut and pan chewing, exposure to venereal diseases. Past history; Tuberculosis, Leprosy, Syphilis, Septic focus in E.N.T., such as chronic tonsillitis, sinusitis etc. General and systemic examination of the patient.

Detailed routine ear, nose and throat examination of the patient with indirect laryngoscopy or video laryngoscopy with angled scope in difficult cases and examination of the neck. The provisional diagnosis was made with this data

\section{Results And Observations}

The 40 patients underwent detailed clinical examination and Histopathological examination. The biopsy specimens were examined at Dept. of Pathology Dr. V. M. Govt Medical College Solapur

\section{Age \& Sex}

Benign lesions of larynx were found more commonly in males i.e. 25 cases $(62.5 \%)$ with male to female ratio being 1.67:1. The maximum number of cases were between $21-50$ years i.e. 33 cases $(82.5 \%)$ in which maximum number were between $21-30$ years i.e.15 cases (37.5\%). The incidence found to be decreasing below and above 20 and 50 years respectively.The youngest patient was 9 year old and the oldest was of 62 years.

\section{Occupation}

Maximum number of cases were found to be housewife i.e. 10 cases (25\%), followed by teachers $(15 \%)$, students $(12.5 \%)$, singers and hawkers forming other common group of patient with benign lesions of larynx in that order.

\section{Predisposing Factors}

Vocal overuse or vocal abuse was found to be commonest habit both in males and females i.e. total 25 cases (62.5\%) followed by use of other tobacco preparation (37.5\%) other than cigarette and bidi, smoking and alcohol consumption $(20 \%)$ in that order were found to be other common habits predominantly in males. 7 cases were not giving any history of habits ( 5 male; 2 female), those constituted 2 cases of laryngeal papillomatosis, 2 cases of vocal nodules and 1 case each of rhinoscleroma (scleroma of larynx, vocal polyp and chronic laryngitis.

\section{Symptoms}

Change in voice or hoarseness of voice was the commonest symptom found in $40(100 \%)$ cases followed by voice fatiguability $(48.5 \%)$ as second most common symptom. Few patients also had other symptoms like cough/repeated attacks of upper respiratory tract infection $(32.5 \%)$, discomfort in throat $(22.5 \%)$, foreign body sensation in throat (10\%), throat pain $(15 \%)$ and inability to raise voice; but these symptoms were less frequent. One case also presented with dyspnoea.

\section{Incidence of Various Benign Lesions}

Maximum number of cases were found to be of vocal cord nodule i.e. 18 cases $(45 \%)$ followed by vocal cord polyp i.e. 11 cases (27.5\%) and couple of cases of vocal cord cyst, chronic laryngitis, reinke'soedema, vocal cord keratosis and laryngeal papillomatosis each and one case of rhinoscleroma (Scleroma of larynx). 


\section{Discussion}

Benign lesions of larynx are significant because of the importance of spoken or sung communication and the voice's contribution to identity. Benign laryngeal lesions are not a rare entity. It may be large enough to obstruct the airway and threaten the life of an individual or may produce hoarseness of voice, jeopardizing the livelihood of same. ${ }^{5}$

Majority of the results of our study were in concurrence with results of similar study.

\section{Age \& Sex}

In our study, age of patient with benign lesion of larynx ranged from 9 yrs. to 62 yrs. with majority of patients were in the age group of 21-30 yrs. (i.e. 15 cases; 37.5\%) followed by age group 31-40 yrs. (i.e. 13 case; $32.5 \%$ ) with minimum number cases in age group of 1-10 yrs, 51-60 yrs. and > 60 yrs. (i.e. 1 case each). These results of agewise distribution of cases were comparable to other similar studies done by Singhalet al ${ }^{9}$; Swapan Ghosh et $\mathrm{al}^{6}$ and Baitha et $\mathrm{al}^{11}$.

In our study $85 \%$ of cases were found in age group of $20-50$ yrs. which was comparable to other similar studies done by Chopra H. and Kapoor $\mathrm{M}^{5}$.

In our study, benign lesions of larynx were found to be more common in male (i.e. 24 cases; 62.5\%) than in female (i.e. 15 cases; $37.5 \%$ ); These results were comparable with the other study by Wani et $\mathrm{al}^{7}$.

In our study, vocal nodule was the only benign lesion in which there was female preponderance while in vocal cord cyst and chronic laryngitis, male and female had equal distribution of cases. Vocal cord polyp, reinke'soedema, keratosis, rhinoscleroma (scleroma of larynx) were more common in males.

\section{Occupation}

In our study, majority of patient were housewife (i.e. 10 case; $25 \%$ ) followed by other professional voice users like teacher (6 case; $15 \%)$ student ( 5 cases; $12.5 \%)$ singers (5 cases; $12.5 \%)$ and hawkers (5 cases; $12.5 \%)$.

These findings were comparable with the other similar studies by Chopra H. and Kapoor M. et $\mathrm{al}^{5}$ and Swapan Ghosh et $\mathrm{al}^{6}$. In study by Chopra H., Kapoor M. ${ }^{5}$ et al there were $25.37 \%$ patient were housewives; $10.45 \%$ patient were teacher, $12 \%$ patient were student and $5.9 \%$ patient were hawker while in study by Swapan Ghosh et $\mathrm{al}^{6}$ housewives comprised major group of study with $29 \%$ of all patient followed by student (16\%); teacher $(6 \%)$ and singer $(5 \%)$.

In our study, other observed occupation were labourers (4 cases ; 10\%); Auto driver (2 cases; $5 \%$ ); LIC agent, bus conductor and social worker ( 1 case each; $2.5 \%$ each). Although the number of male patients in the study were more by occupational incidence in females was found to be significantly larger housewives ( 10 cases $25 \%$ ), teacher (6 cases $15 \%$ ), concordance with Chopra H. and Kapoor M. et al ${ }^{5}$ and Swapan Ghosh et al ${ }^{6}$.

\section{Habits}

In our study commonest habit noted was vocal overuse or vocal abuse observed in 25 case i.e. $62.5 \%$ of all cases; this finding was comparable with other similar study by Swapan Ghosh et al ${ }^{6}$ (72\% patient with vocal abuse/overuse); Wani et al ${ }^{7}$ study (45\%) and Parikh N. P. ${ }^{8}(56 \%)$. Second most common habit observed was use of tobacco preparation other than smoking like chewing of tobacco, pan, mishri etc. which was observed in 15 case (37.5\%), out of 15 cases, 2 were female. Other habit like smoking was observed in 11 cases $(27.5 \%)$; finding was comparable with study by Wani and et $\mathrm{al}^{7}$, and alcoholism was found in 8 case (20\%).

7 patients did not give history of any habits out of which 2 were females and 5 were males. These constitute 2 cases of laryngeal papillomatosis, 2 cases of vocal nodule and 1 case of each of rhinoscleroma (scleroma of larynx), vocal polyp and chronic laryngitis.

\section{Clinical Presentation}

Change in voice or Hoarseness of voice was found to be most common presenting symptoms i.e. in all 40 cases $(100 \%)$ in our study, comparable to other similar studies by Singhalet al ${ }^{9}$, Pankaj Kumar Doloi and Swagata Khanna ${ }^{10}$, Baitha et al ${ }^{11}$ and Hegade et $\mathrm{al}^{12}$.Voice fatigue was observed to be second most common symptom (in 19 patient i.e. $48.5 \%$ ) in our study which was comparable to the study by Singhal et $\mathrm{al}^{9}$ and Pankaj Kumar Doloi and Swagata Khanna ${ }^{10} .13$ patients i.e. $32.5 \%$ of patients were also complained of cough or repeated attacks of upper respiratory tract infection; this finding was comparable with the study Singhal et $\mathrm{al}^{9}$, Pankaj Kumar Doloi and Swagata Khanna ${ }^{10}$, Baitha et al ${ }^{11}$ and Hegade et $\mathrm{al}^{12}$.Discomfort in throat was complained by 9 patient i.e. $22.5 \%$ of patient in our study which was comparable with the findings of other study by Singhalet $\mathrm{al}^{9}$, Baitha et al ${ }^{11}$ and Wani et al ${ }^{7}$.Throat pain was observed in 6 patient i.e. $15 \%$ of all patient in our study, these finding were comparable with the findings in other studies by Singhalet $\mathrm{al}^{9}$, Wani et $\mathrm{al}^{7}$, Baitha et $\mathrm{al}^{11}$ and Hegade et $\mathrm{al}^{12} .4$ patient i.e. $10 \%$ of all cases in our study also complained of foreign body 
sensation in throat; this finding were comparable with the findings in other study by Singhal et al ${ }^{9}$, Pankaj Kumar Doloi and Swagata Khanna ${ }^{10}$, Wani et $\mathrm{al}^{7}$ and Hegade et $\mathrm{al}^{12} .1$ patient $(2.5 \%)$ of our study with diagnosis of Reinke'soedema also complained of inability to raise voice and 1 patient of rhinoscleroma (scleroma of larynx) also complained of dyspnoea or stridor in our study.

\section{Conclusion}

The benign laryngeal lesions produces symptoms which range from hoarseness in voice to life threatening respiratory distress. These can put a lot of cost and disability burden on professional voice users, also create lot of emotional and mental tension in lives of patient and patient's families. All the available methods of study should be utilized to make the diagnosis as early as possible. Early diagnosis can alleviate a lot of aforementioned ills for the patient and their families. As such, the standard treatment of choice in all types of benign tumors of larynx should consist microlaryngeal surgery, voice rest and voice rehabilitation

\section{Bibliography}

[1]. Pradhan S. Voice conservative surgery inlaryngealcancer. $1^{\text {st }}$ edition. Mumbai: Lloyds publishing house; 1997;Chapter 1: p.1.

[2]. Sharma DK, Sohal BS, Bal MS, Aggarwal S. Clinico-Pathological Study of 50 Cases of Tumours of Larynx. Indian Journal of Otolaryngology and Head \& Neck Surgery. 2013;65(Suppl 1):29-35.

[3]. Gaelyn GC, Ossof RH. Hoarseness. Medical Clinics of North America. 1999, Jan; 83:115-123.

[4]. New GB and Erich JB. Benign tumours of the larynx- a Study of 722 cases. Archieves of Otolaryngology. 1938; 28(6):841-910.

[5]. Chopra H, Kapoor M. Study of benign glottic lesions undergoing microlaryngeal surgery. Indian Journal of Otolaryngology and Head and Neck Surgery. 1997; 49(3):276-279

[6]. Ghosh SK, Chattopadhyay S, Bora H, Mukherjee PD. Microlaryngoscopic study of 100 cases of hoarseness of voice. Indian Journal of Otolaryngology and Head and Neck Surgery. 2001, Oct-Dec; 53(4):270-72.

[7]. Wani AA, Rehman A, Hamid S, Akhter M, Baseena S. Benign Mucosal Fold Lesion as a Cause of Hoarseness of Voice. A Clinical Study. Otolaryngology. 2012;2(3):120.

[8]. Parikh N P. Aetiological study of 100 cases of hoarseness of Voice. Indian Journal of Otolaryngology and Head and Neck Surgery; 1991; 43(2):71-73.

[9]. Singhal P, Bhandari A, Chouhan M, Sharma MP, Sharma S. Benign tumours of larynx- A clinical study of 50 cases. Indian Journal of Otolaryngology and Head and Neck Surgery. 2009, March; 61(1):26-30.

[10]. Doloi PK, Khanna S. A Study of Management of Benign Lesions of Larynx. International Journal of Phonosurgery and Laryngology. 2011, July-December;1(2):61-64.

[11]. Baitha S, Raizada RM, Singh AKK, Puttewar MP, Chaturvedi VN. Clinical profile of hoarseness of voice. Indian Journal of Otolaryngology and Head Neck Surgery. 2002;54(1):14-18

[12]. Hegde MC, Kamath MP, Bhojwani K, Peter R, Babu PR. Benign lesions of larynx-A clinical study. Indian Journal of Otolaryngology and Head \& Neck Surgery. 2005;57(1):35-38. doi:10.1007/BF02907624.

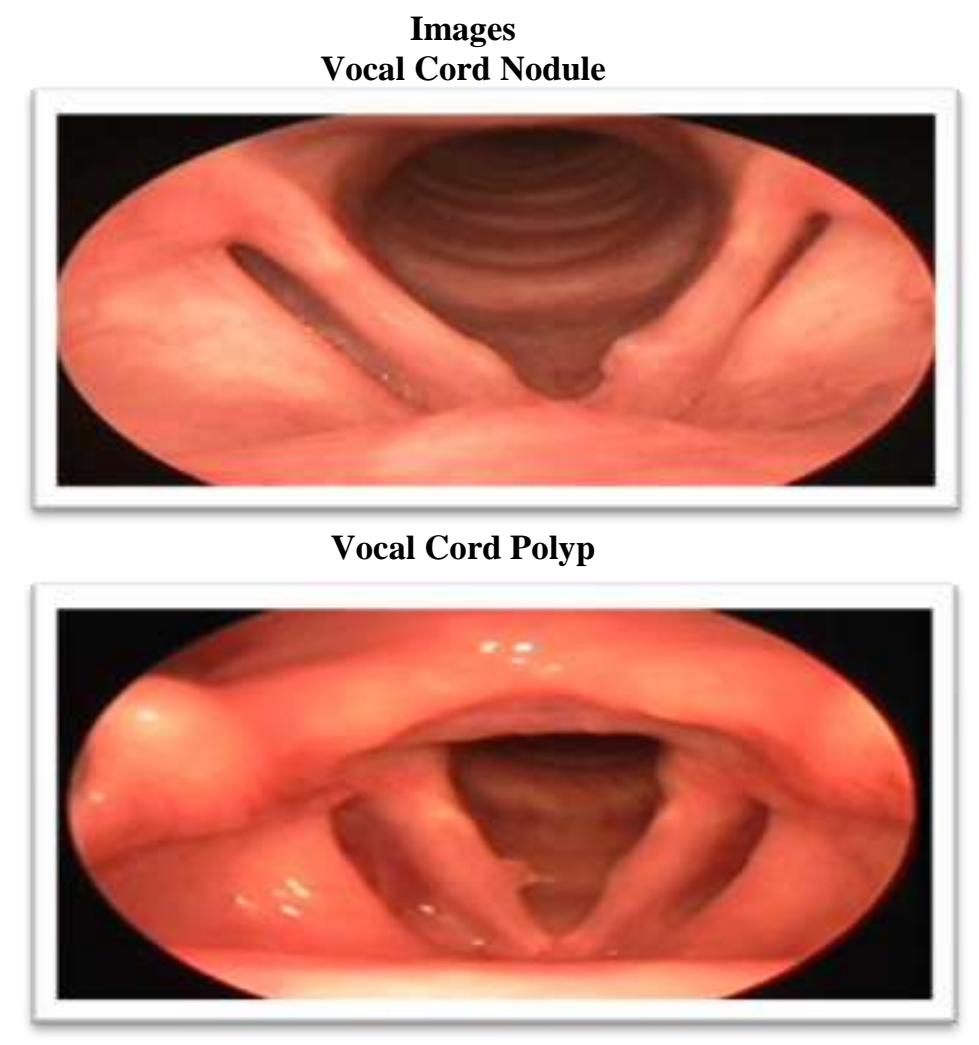


Rhinoscleroma (ScleromaOf Larynx)

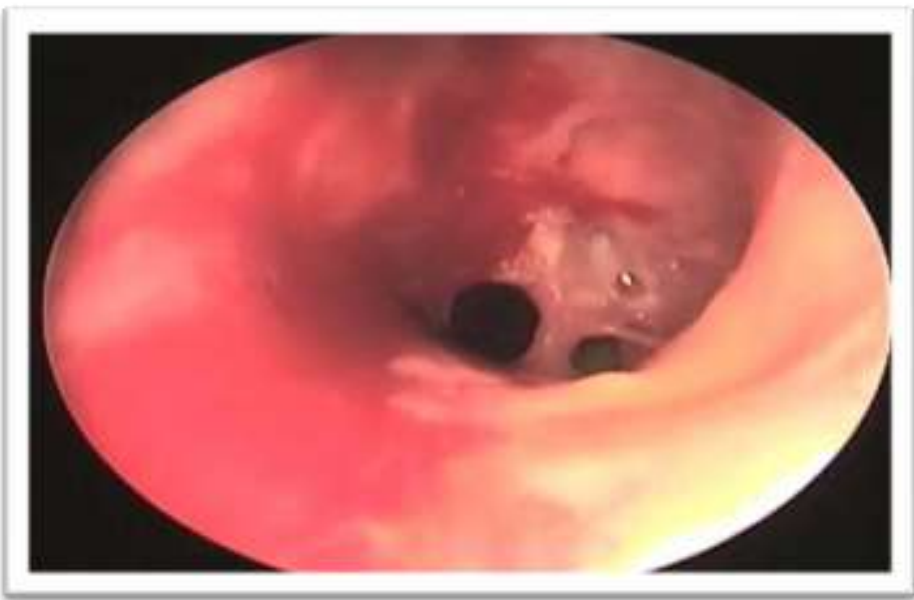

Vocal Cord Polyp

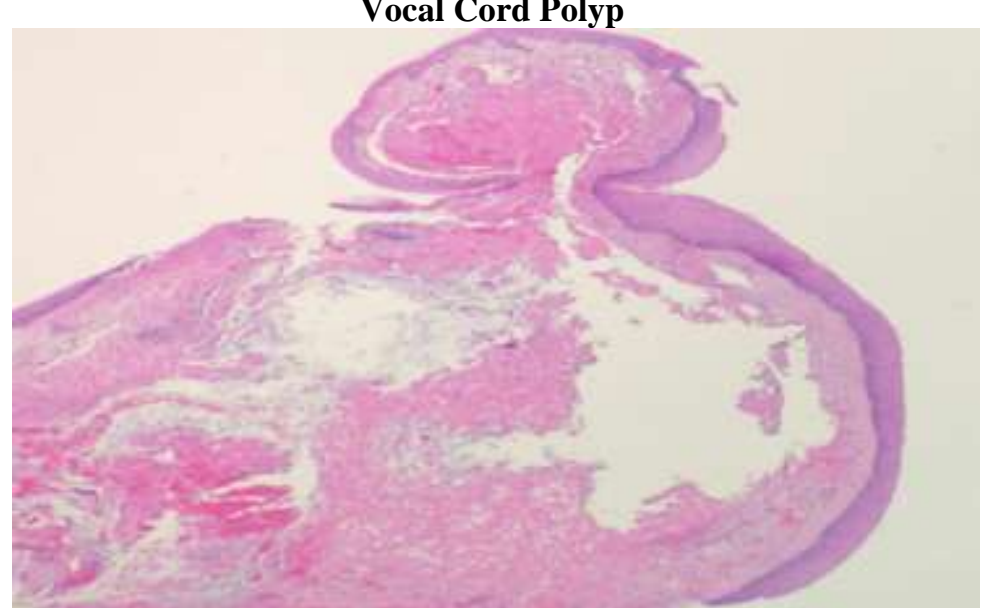

Vocal Nodule

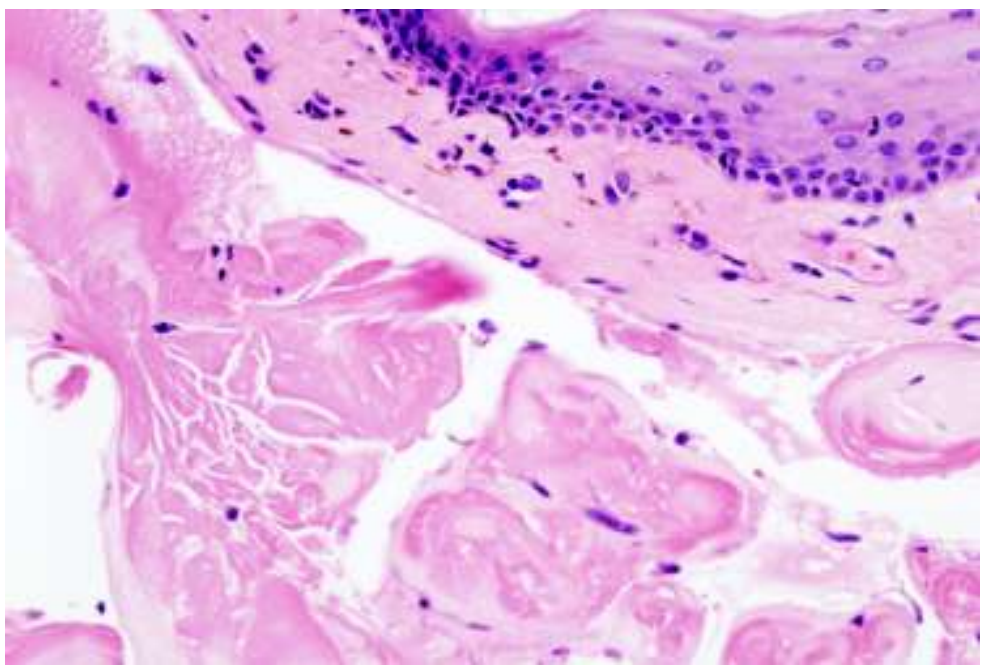




\section{Charts And Tables}

Table no. 1-Showing sex wise distribution of cases of benign lesions of larynx

\begin{tabular}{|l|l|l|}
\hline \multirow{2}{*}{ SEX } & \multicolumn{2}{|l|}{ NO. OF CASES OF BENIGN LESIONS OF LARYNX } \\
\cline { 2 - 3 } MALE & NUBER & PERCENTAGE \\
\hline FEMALE & 25 & 62.5 \\
\hline TOTAL & 15 & 37.5 \\
\hline
\end{tabular}

\section{SEXWISE DISTRIBUTION OF CASES OF} BENIGN LESIONS OF LARYNX

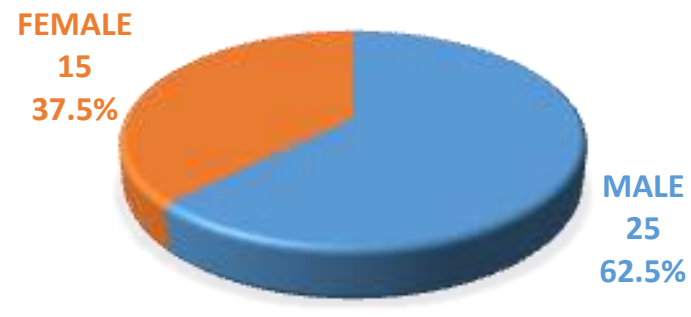

Table No. 2 :Showing age wise distribution of cases of benign lesions Larynx

\begin{tabular}{|l|l|l|}
\hline \multirow{2}{*}{ AGE IN YEARS } & NUMBER OF CASES OF BENIGN LESIONS \\
\cline { 2 - 3 } & NUMBER & PERCENTAGE \\
\hline$<10$ yrs & 01 & 2.5 \\
\hline $11-20$ & 04 & 10 \\
\hline $21-30$ & 15 & 37.5 \\
\hline $31-40$ & 13 & 32.5 \\
\hline $41-50$ & 05 & 12.5 \\
\hline $51-60$ & 01 & 2.5 \\
\hline $61-70$ & 01 & 2.5 \\
\hline TOTAL & 40 & 100 \\
\hline
\end{tabular}

\section{AGEWISE DISTRIBUTION OF CASES OF BENIGN LESIONS OF LARYNX}

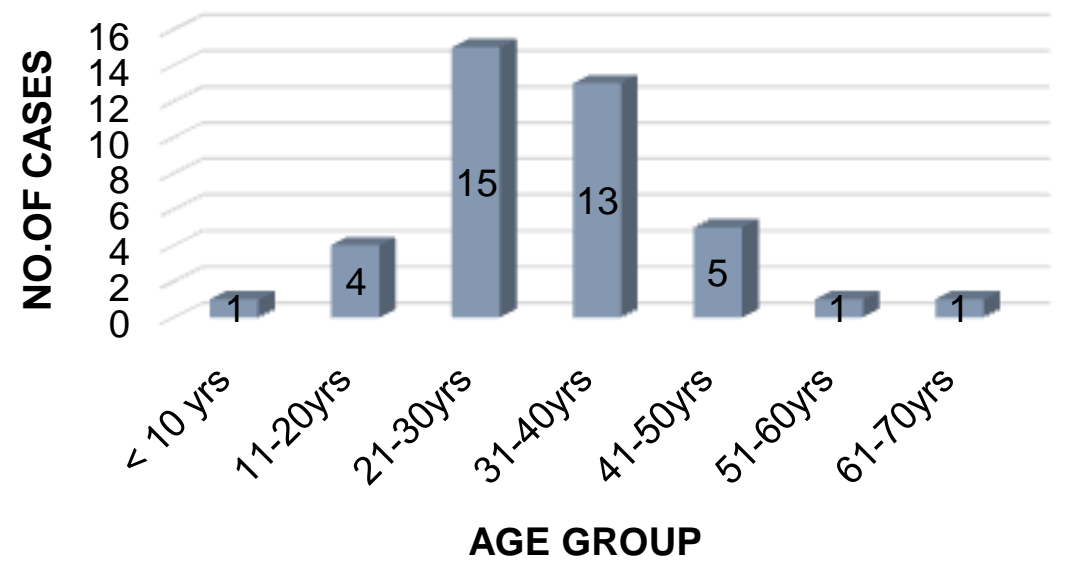

Table no. 3 :Incidence of benign lesions of larynx in male and female

\begin{tabular}{|l|l|l|l|l|l|}
\hline $\begin{array}{l}\text { SR. } \\
\text { NO. }\end{array}$ & CLINICAL DIAGNOSIS & $\begin{array}{l}\text { NO.OF } \\
\text { MALES }\end{array}$ & $\begin{array}{l}\text { NO.OF } \\
\text { FEMALES }\end{array}$ & TOTAL & \% \\
\hline 1 & VOCAL CORD NODULE & 08 & 10 & 18 & 45 \\
\hline 2 & VOCAL CORD POLYP & 08 & 03 & 11 & 27.5 \\
\hline 3 & VOCAL CORD CYST & 01 & 01 & 02 & 5.0 \\
\hline 4 & CHRONIC LARYNGITIS & 01 & 01 & 02 & 5.0 \\
\hline
\end{tabular}


Benign Lesions Of Larynx - A Clinicopathological Study

\begin{tabular}{|l|l|l|l|l|l|}
\hline 5 & REINKES OEDEMA & 02 & 00 & 02 & 5.0 \\
\hline 6 & VOCAL CORD KERATOSIS & 02 & 00 & 02 & 5.0 \\
\hline 7 & LARYNGEAL PAPILLOMATOSIS & 02 & 00 & 02 & 5.0 \\
\hline 8 & $\begin{array}{l}\text { RHINOSCLEROMA (SCLEROMA } \\
\text { OF LARYNX) }\end{array}$ & 01 & 00 & 01 & 2.5 \\
\hline \multicolumn{2}{|l|}{ TOTAL } & 25 & 15 & 40 & 100 \\
\hline
\end{tabular}

\section{INCIDENCE OF BENIGN LESIONS OF LARYNX IN} MALE AND FEMALE
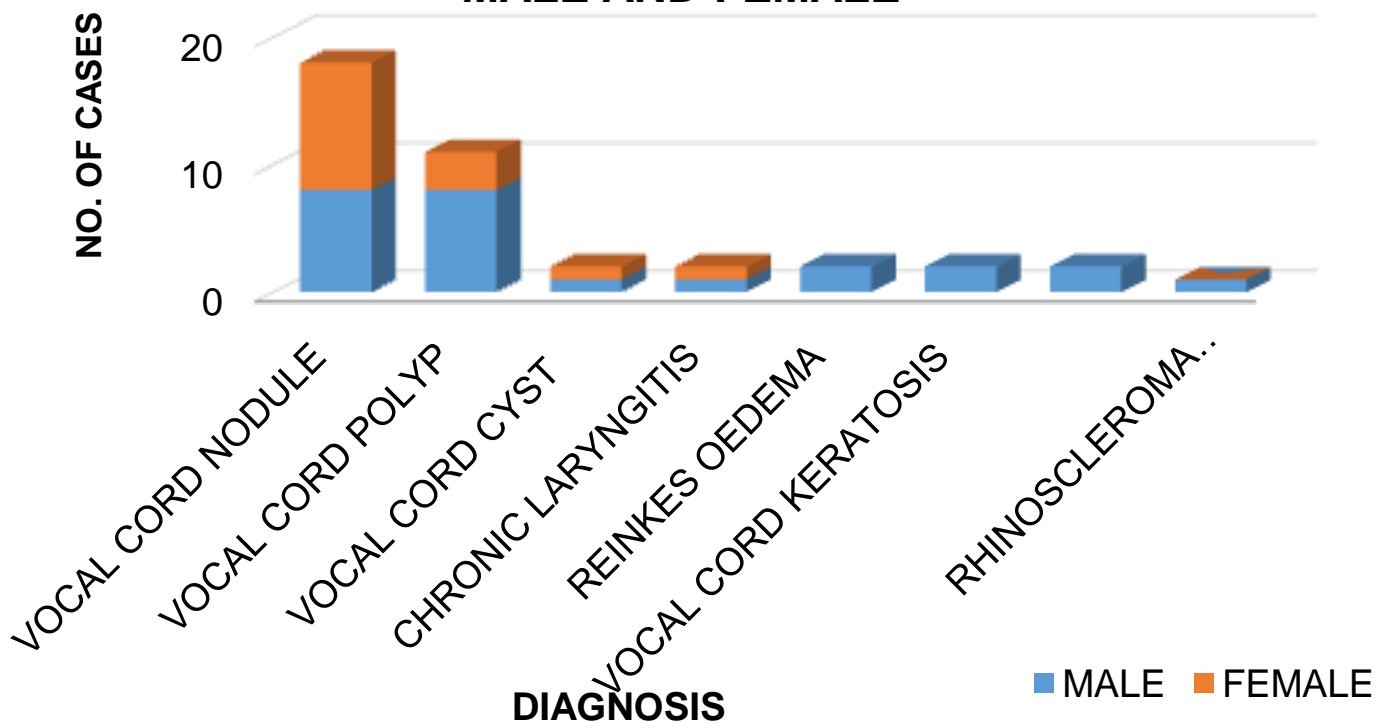

Table no. 4 :Showing distribution of cases according to symptoms

\begin{tabular}{|l|l|l|l|}
\hline SR. NO. & SYMPTOMS & NO.OF CASES & PERCENTAGE \\
\hline 1 & CHANGE IN VOICE/HOARSENESS OF VOICE & 40 & 100 \\
\hline 2 & FATIGUE OF VOICE & 19 & 48.5 \\
\hline 3 & COUGH / REPEATED ATTACKS OF URTI & 13 & 32.5 \\
\hline 4 & IRRITATION / DISCOMFORT IN THROAT & 09 & 22.5 \\
\hline 5 & F.B. SENSATION IN THROAT & 04 & 10.0 \\
\hline 6 & THROAT PAIN & 06 & 15.0 \\
\hline 7 & INABILITY TO RAISE VOICE & 01 & 2.5 \\
\hline 8 & DYSPNOEA / STRIDOR & 01 & 2.5 \\
\hline
\end{tabular}

Table No. 5 :Showing distribution of cases according to habits

\begin{tabular}{|c|c|c|c|c|c|c|}
\hline \multirow[t]{2}{*}{ HABITS } & \multicolumn{2}{|c|}{ NO.OF MALES } & \multicolumn{2}{|c|}{ NO.OF FEMALE } & \multicolumn{2}{|l|}{ TOTAL } \\
\hline & NUMBER & $\%$ & NUMBER & $\%$ & NUMBER & $\%$ \\
\hline SMOKING & 11 & 27.5 & 00 & 00 & 11 & 27.5 \\
\hline OTHER TOBACCO & 12 & 30 & 03 & 7.5 & 15 & 37.5 \\
\hline $\begin{array}{l}\text { PREPARATION } \\
\text { (GUTAKHA, } \\
\text { MISHRI, ETC) }\end{array}$ & & & & & & \\
\hline ALCOHOL & 08 & 20 & 00 & 00 & 08 & 20 \\
\hline $\begin{array}{l}\text { VOCAL } \\
\text { OVERUSE/ABUSE }\end{array}$ & 13 & 32.5 & 12 & 30 & 25 & 62.5 \\
\hline NO HABITS & 05 & 12.5 & 02 & 05 & 07 & 17.5 \\
\hline
\end{tabular}




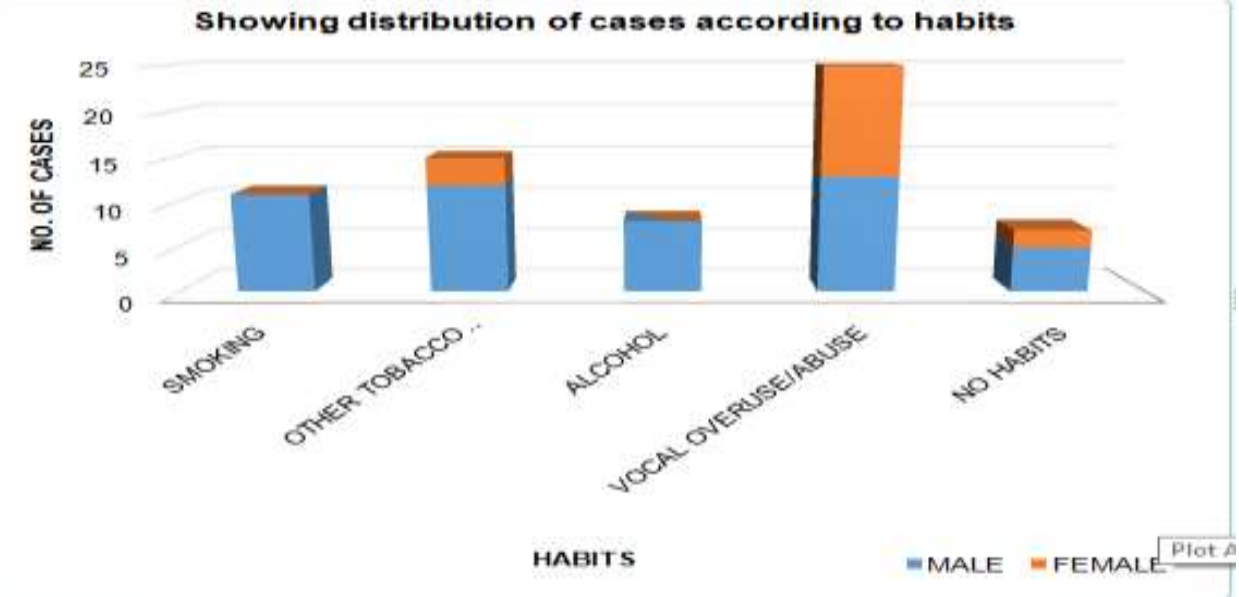

Table No. 6 : Showing distribution of cases of benign lesions of larynx according to occupation

\begin{tabular}{|l|l|l|l|}
\hline SR.NO & OCCUPATION & NO.OF CASES & PERCENTAGE \\
\hline 1 & HOUSEWIFE & 10 & 25 \\
\hline 2 & TEACHER & 06 & 15 \\
\hline 3 & STUDENT & 05 & 12.5 \\
\hline 4 & SINGER & 05 & 12.5 \\
\hline 5 & HAWKERS & 05 & 12.5 \\
\hline 6 & LABOURER & 04 & 10 \\
\hline 7 & $\begin{array}{l}\text { OTHER (SOCIAL WORKER, LIC AGENT, } \\
\text { BUS CONDUCTOR, AUTO DRIVER) }\end{array}$ & 05 & 12.5 \\
\hline & TOTAL & $\mathbf{4 0}$ & $\mathbf{1 0 0}$ \\
\hline
\end{tabular}

\section{DISTRIBUTION OF CASES OF BENIGN LESIONS OF LARYNX ACCORDING TO OCCUPATION}

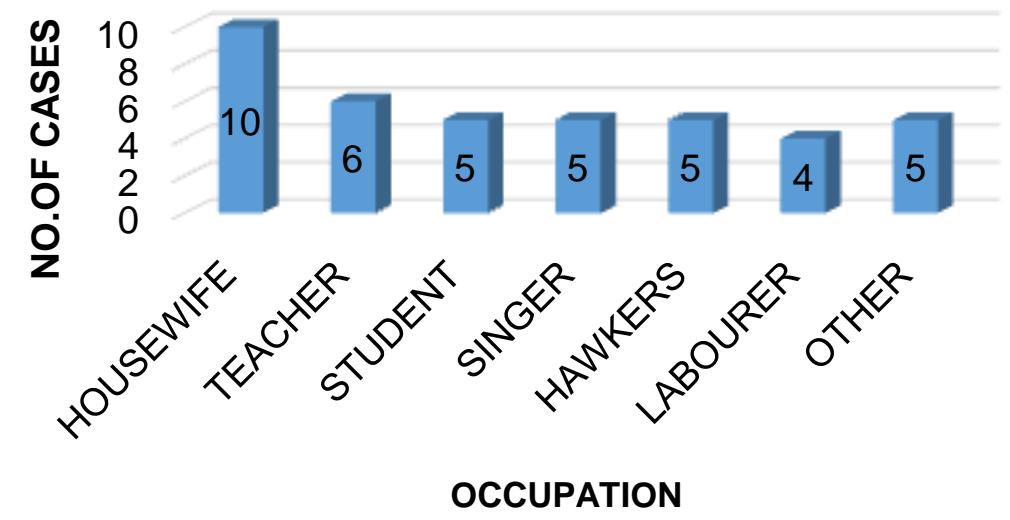

Table no. 8 : Showing distribution of cases according to histopathological report

\begin{tabular}{|l|l|l|}
\hline $\begin{array}{l}\text { SR. } \\
\text { NO. }\end{array}$ & HISTOPATHOLOGICAL DIAGNOSIS & $\begin{array}{l}\text { NO.OF } \\
\text { CASES }\end{array}$ \\
\hline 1 & Epithelial hyperplasia with subepithelial fibrous tissue suggestive of vocal nodule & 18 \\
\hline 2 & Inflammatory polyp & 11 \\
\hline 3 & Cyst & 02 \\
\hline 4 & $\begin{array}{l}\text { Epithelial hyperplasia with dilated vessels and mononuclear cell infiltration suggestive of } \\
\text { chronic laryngitis }\end{array}$ & 02 \\
\hline 5 & Edema of subepithelial space suggestive of rienke's edema & 02 \\
\hline 6 & Vocal cord keratosis & 02 \\
\hline 7 & Laryngeal epithelial papilloma & 02 \\
\hline 8 & Rhinoscleroma (Scleroma of larynx) & 01 \\
\hline & TOTAL & $\mathbf{4 0}$ \\
\hline
\end{tabular}




\section{DISTRIBUTION OF CASES ACCORDING TO HISTOPATHOLOGICAL REPORT}

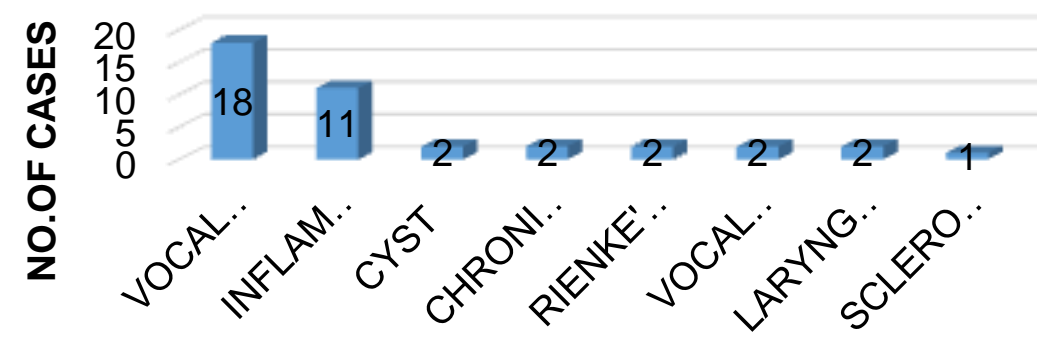

HISTOPATHOLOGICAL DIAGNOSIS

\begin{tabular}{|l|l|l|l|l|}
\hline \multirow{2}{*}{$\begin{array}{l}\text { Age Group In } \\
\text { Years }\end{array}$} & \multicolumn{4}{|l|}{ Studies showing age wise distribution of number of cases } \\
\cline { 2 - 5 } & Present Study (n=40) & $\begin{array}{l}\text { Singhal P. et al Study } \\
(\mathbf{n = 5 0})\end{array}$ & $\begin{array}{l}\text { Swapan Ghosh et } \\
\text { al study }(\mathbf{n = 1 0 0})\end{array}$ & $\begin{array}{l}\text { Baitha et al } \\
\text { study } \\
(\mathbf{n}=\mathbf{1 1 0})\end{array}$ \\
\hline$<10$ yrs. & $01(2.5 \%)$ & $0(0)$ & $04(4 \%)$ & $03(2.72 \%)$ \\
\hline $11-20$ yrs. & $04(10 \%)$ & $4(8 \%)$ & $18(18 \%)$ & $09(8.18 \%)$ \\
\hline $21-30$ yrs. & $15(37.5 \%)$ & $17(34 \%)$ & $28(28 \%)$ & $20(18.18 \%)$ \\
\hline $31-40$ yrs. & $13(32.5 \%)$ & $13(26 \%)$ & $20(20 \%)$ & $31(28.18 \%)$ \\
\hline $41-50$ yrs. & $05(12.5 \%)$ & $09(18 \%)$ & $18(18 \%)$ & $17(15.45 \%)$ \\
\hline $51-60$ yrs. & $01(2.5 \%)$ & & $05(5 \%)$ & $15(13.63 \%)$ \\
\hline$>60$ yrs. & $01(2.5 \%)$ & $07(7 \%)$ & $15(13.63 \%)$ \\
\hline
\end{tabular}

